\title{
Role of the TRPM4 Channel in Cardiovascular Physiology and Pathophysiology
}

\author{
Chen Wang, Keiji Naruse and Ken Takahashi * (D) \\ Department of Cardiovascular Physiology, Graduate School of Medicine, Dentistry and Pharmaceutical Sciences, \\ Okayama University, Okayama 700-8558, Japan; wangchen11228@gmail.com (C.W.); \\ knaruse@md.okayama-u.ac.jp (K.N.) \\ * Correspondence: takah-k2@okayama-u.ac.jp; Tel.: +81-86-235-7119
}

Received: 11 May 2018; Accepted: 14 June 2018; Published: 15 June 2018

\begin{abstract}
The transient receptor potential cation channel subfamily M member 4 (TRPM4) channel influences calcium homeostasis during many physiological activities such as insulin secretion, immune response, respiratory reaction, and cerebral vasoconstriction. This calcium-activated, monovalent, selective cation channel also plays a key role in cardiovascular pathophysiology; for example, a mutation in the TRPM4 channel leads to cardiac conduction disease. Recently, it has been suggested that the TRPM4 channel is also involved in the development of cardiac ischemia-reperfusion injury, which causes myocardial infarction. In the present review, we discuss the physiological function of the TRPM4 channel, and assess its role in cardiovascular pathophysiology.
\end{abstract}

Keywords: TRPM4 channel; cardiovascular system; physiology; pathophysiology

\section{Introduction}

The transient receptor potential (TRP) melastatin-like subfamily member 4 (TRPM4) is a 1214-amino-acid-long transmembrane protein encoded by TRPM4, which is located on human chromosome 19 [1,2]. As a member of the TRP family, it participates in mediating the flux of $\mathrm{Na}^{+}$ and $\mathrm{K}^{+}$across the plasma membrane into the cytoplasm [3]. In contrast to most of the functionally characterized TRP channels, which are nonselective $\mathrm{Ca}^{2+}$-permeable cation channels, TRPM4 and TRPM5 are permeable only to monovalent cations, and not to $\mathrm{Ca}^{2+}$ or $\mathrm{Mg}^{2+}$. The $\mathrm{Ca}^{2+}$ impermeability of the TRPM4 channel plays a role in the accumulation of intracellular $\mathrm{Ca}^{2+}$, which leads to the depolarization of the plasma membrane [2-5]. Although it is impermeable to $\mathrm{Ca}^{2+}$, TRPM4 is a $\mathrm{Ca}^{2+}$ - and voltage-activated channel, and its activation is regulated via a variety of methods. Phosphatidylinositol 4,5-bisphosphate ( $\left.\mathrm{PIP}_{2}\right)$ is an effective modulator of TRPM4 as the channel can be rapidly desensitized to intracellular $\mathrm{Ca}^{2+}[6,7]$. In addition, adenosine triphosphate (ATP), protein kinase $\mathrm{C}$ (PKC)-dependent phosphorylation, and calmodulin (CaM) also play a role in TRPM4 activation [8-11], which will be discussed later on in the review.

Like other TRP channels, TRPM4 also comprises six transmembrane domains. The $\mathrm{NH}_{2}$ and $\mathrm{COOH}$ terminal regions of TRPM4 contain binding sites that are related to the channel's activation [1,10]. TRPM4 is highly expressed in a number of tissues and organs and involved in complicated physiological and pathological mechanisms, especially in calcium-dependent mechanisms, such as insulin secretion, immune response, respiratory reaction, tumor development, and cardiovascular diseases [12-15]. Cardiovascular risks have a detrimental impact on human health, and some research has implicated TRPM4 in cardiac hypertrophy, myocardial ischemia-reperfusion injury (IRI), and hereditary arrhythmia [16-24]. In the present review, we focus on the physiological role of TRPM4, and discuss its involvement in cardiovascular pathophysiology. 


\section{Physiological Characteristics of TRPM4}

\subsection{TRP Overview}

TRP cation channels were first reported in Drosophila spp. In 1975, and over 50 family members have been characterized to date $[1,25]$. In general, they can be divided into seven subfamilies in accordance with the amino acid sequence homology: TRPC, TRPV, TRPM, TRPP, TRPML, TRPA, and TRPN. At present, 28 genes of the TRP family have been found to be expressed in mammalians in succession, but only 27 different members are in humans $[1,3,26]$. The biophysical properties of TRP family members have been described previously according to the reviews of Clapham et al., Watanabe et al., and Zheng et al. [11,15,26,27]. As mentioned earlier, all the TRPs contain six transmembrane domains and are tetramerized to form functional channels. Therefore, the classical structure of multiple cation channels is mimicked, such as voltage-dependent ion channels. It is well known that $\mathrm{Ca}^{2+}$ is involved in many important cellular response mechanisms as a major intracellular messenger [27-29]. The changes in intracellular $\mathrm{Ca}^{2+}$ concentration are closely related to the physiological and pathological mechanisms in important tissue systems; for example, alteration in calcium concentration in culture medium affects epidermal cell proliferation and differentiation [30].

It is widely acknowledged that the dynamic stability of extracellular and intracellular $\mathrm{Ca}^{2+}$ is beneficial to bone health and in maintaining the endocrine balance [31-33]. In recent years, intracellular $\mathrm{Ca}^{2+}$ overload has been regarded as key in a series of cardiovascular risks such as coronary artery diseases, arrhythmia, and cardiac failure; and clinically, calcium antagonists have been used effectively in treating angina, hypertension, and supraventricular tachyarrhythmias, which illustrates that maintenance of $\mathrm{Ca}^{2+}$ homeostasis confers cardioprotective benefits [34-40]. a majority of TRP channels are permeable to $\mathrm{Ca}^{2+}$ and play a unique role as cell sensors [41]. They are involved in various cellular functions mediated by $\mathrm{Ca}^{2+}$, such as contraction, proliferation, and apoptosis [42-44]. In other words, TRP channels act as gatekeepers in homeostasis [14,45-48]; for example, it has been reported that the TRP channels maintain the dynamic equilibrium between $\mathrm{Mg}^{2+}$ and $\mathrm{Ca}^{2+}$ in epithelial tissues [49].

The multiple functions played by the TRP channels and their activated multimodality characteristics imply that correct channel gating or infiltration may facilitate the study of complex pathophysiological mechanisms [1,14,16,50]. In the last ten years, several studies from Nilius et al., Watanabe et al., and Kaneko et al. have successively shown that TRP channels are highly expressed in the gastrointestinal tract, genitourinary system, immune system, endocrine system, respiratory system, nervous system, and cardiovascular system, which are involved in complicated physiological and pathological processes [12-14].

In contrast to other TRP family members, TRPM4 can be activated by an intracellular accumulation of $\mathrm{Ca}^{2+}[8,51]$. In addition, TRPM4 is permeable to the monovalent cations with the following ionic selectivity: $\mathrm{Na}^{+}>\mathrm{K}^{+}>\mathrm{Cs}^{+}>\mathrm{Li}^{+}$[52]. However, TRPM4 shows no $\mathrm{Ca}^{2+}$ permeability, which induces intracellular $\mathrm{Ca}^{2+}$ accumulation and overload to cause depolarization of the cell membrane, which further leads to cell damage or death [2,15]. Therefore, we will systematically analyze the physiological and pathological role of TRPM4 in the cardiovascular system as far as the specificity of TRPM4 for the non-permeability of $\mathrm{Ca}^{2+}$ is concerned.

\subsection{Comparison between TRPM4 and TRPM5}

Additionally, TRPM is a multifunctional group of TRP channels. As well as other TRPs, the majority of TRPM members are cation channels with $\mathrm{Ca}^{2+}$-permeability, except for TRPM4 and TRPM5. It has been described that there is 50\% amino acid sequence homology between the two channels [1,4]. The activity of TRPM5 is also initiated by a rise in the intracellular $\mathrm{Ca}^{2+}$, which is quite similar to TRPM4, also being involved in numerous physiological and pathological mechanisms by modulating $\mathrm{Ca}^{2+}$ homeostasis. For example, according to Banik et al., TRPM4 and TRPM5 are both essential in transduction of taste stimuli [53]. Additionally, TRPM4 and TRPM5 are regulated by 
voltage and PIP2. TRPM5 has been regarded as a heat-activated channel, which shows temperature sensitivity in the range of $15-35{ }^{\circ} \mathrm{C}$. As a close homolog of TRPM5, the temperature sensitivity of TRPM4 may be similar to that of TRPM5; studies have shown that its voltage-dependent activation curve may turn toward a more negative potential with an increasing temperature [9,54-56].

In contrast to the similarities described above, there are several differences between TRPM4 and TRPM5. For example, the tissue distributions of TRPM4 and TRPM5 are widely divergent. In research by Fonfria and colleagues, compared to TRPM4 expression, TRPM5 expression was observed only in a limited number of tissues including the intestine, pancreas, prostate, kidney, and pituitary. On the other hand, TRPM4 is highly expressed in the heart, lung, brain, bone, and stomach [57]. TRPM4 is involved in action potential generation in mouse atrial cardiomyocytes [58]. In 2014, Demir et al. found that the TRPM4 gene expression was increased slightly after exposure to myocardial ischemia-reperfusion. In contrast, TRPM5 was not detected in the heart [59].

\subsection{TRPM4 Structure}

As a member of the TRP channel family, TRPM4 contains various transmembrane and cytosolic domains that form a three-decker structure [60,61]. There is a wide selectivity filter of TRPM4 that is permeable to the monovalent cations owing to the pore-forming area between the transmembrane domains S5 and S6 $[4,52,62]$. As reported previously, the N-terminal nucleotide-binding domain and the $\mathrm{C}$-terminal coiled coil in the $\mathrm{NH}_{2}$ and $\mathrm{COOH}$ terminal regions influence the tetrameric composition of TRPM4, and two ATP-binding cassette transporter-like motifs at the N-terminal nucleotide-binding domain are involved in the inhibition of TRPM4 activity [60].

Moreover, there are several PKC phosphorylation sites, five CaM-binding sites, four Walker B motifs (which are putative ATP-binding sites), a putative PIP $_{2}$-binding site, and a coiled-coil domain, all of which participate in the modulation of TRPM4 function $[1,10,60]$.

\subsection{Activation of TRPM4}

As a $\mathrm{Ca}^{2+}$ - and voltage-activated channel, there are diverse ways in which TRPM4 is activated, and we will discuss the mechanisms underlying TRPM4 activation in terms of the following modulators: PIP 2 , ATP, PKC-dependent phosphorylation, and CaM.

\subsection{1. $\mathrm{PIP}_{2}$}

$\mathrm{PIP}_{2}$ is a minor phospholipid component of the cell membrane, where it is a substrate for a number of important signaling proteins $[63,64]$. As a substrate of phospholipase C (PLC), $\mathrm{PIP}_{2}$ regulates all types of ion channels and transporters, including the voltage-gated $\mathrm{K}^{+}$and $\mathrm{Ca}^{2+}$ channels $[65,66]$. In 2005-2006, the studies of Zhang et al. and Nilius et al. showed that $\mathrm{PIP}_{2}$ is a powerful enhancer of TRPM4, which may lead to a desensitization effect on TRPM4 activity through PLC-mediated $\mathrm{PIP}_{2}$ decomposition [6,7]. With the hydrolysis of $\mathrm{PIP}_{2}$ in the plasma membrane due to $\mathrm{Ca}^{2+}$-mediated PLC activation, TRPM4 gradually becomes insensitive to $\mathrm{Ca}^{2+}$, which leads to a move toward the state of negative potential $[6,9]$. Under a $\mathrm{Ca}^{2+}$-desensitized condition, TRPM4 shows voltage-dependent gating with increased open-state probability at a depolarizing membrane potential [51,60]. It has been demonstrated that poly-L-lysine, which is a type of $\mathrm{PIP}_{2}$ scavenger, can trigger a sharp desensitization [7].

Previous studies have additionally shown that loss of $\mathrm{PIP}_{2}$ results in a rapid attenuation of the TRPM4 current, in accordance with Nilius et al., which has been detected by adding PIP 2 or inhibiting $\mathrm{PIP}_{2}$ extracellularly of HEK293 cells, both of which can reverse the depletion of the TRPM4 current [6]. Furthermore, depression of PLC activity with U73122, an inhibitor of PLC [67], is also able to preserve the level of $\mathrm{PIP}_{2}[6,9,68]$.

In summary, $\mathrm{PIP}_{2}$ is a critical auxiliary factor in the activation of TRPM4. PIP 2 cannot activate TRPM4 on its own, but can rectify desensitization, increase the sensitivity of TRPM4 to $\mathrm{Ca}^{2+}$, and restrict the voltage dependence of TRPM4 $[6,7,10,69,70]$. To date, two $\mathrm{PIP}_{2}$-binding sites have been discovered 
at the C-terminal of TRPM4, which implies that the alteration of these binding sites may affect the sensitivity of TRPM4 to $\mathrm{PIP}_{2}$ and $\mathrm{Ca}^{2+}[6,71]$.

\subsubsection{ATP}

Owing to the structure of TRPM4, $\mathrm{Ca}^{2+}$ sensitivity of TRPM4 can be modulated by ATP, PKC phosphorylation, and binding of CaM to the C-terminus [8-11]. ATP can restore the $\mathrm{Ca}^{2+}$ sensitivity of TRPM4 after desensitization has been clarified previously [8]. In the absence of $\mathrm{Ca}^{2+}$, TRPM4 can revert from desensitization when the cytoplasmic side of the membrane is exposed to $\mathrm{Mg}^{2+}$-chelated ATP $[8,9]$. However, TRPM4 currents would attenuate in the case of ATP deficiency after recovery. Therefore, addition or depletion of ATP has become vital in regulating the activation of TRPM4. As mentioned earlier, the ATP-binding sites, which include two Walker B motifs in the N-terminus and $\mathrm{ABC}$ transporter signature motifs, can be predicted from the amino acid sequence of TRPM4 [8,72,73]. It was also reported that TRPM4 currents are eliminated sharply when all the sites predicted to affect the ATP-binding of the channel carry mutations, which suggests that ATP is involved in the preservation of TRPM4's $\mathrm{Ca}^{2+}$ sensitivity [8].

\subsubsection{PKC Phosphorylation}

PKC-mediated TRPM4 phosphorylation can increase the $\mathrm{Ca}^{2+}$ sensitivity of TRPM4. A PKC activator, phorbol 12-myristate 13-acetate (PMA), can reduce the Half maximal effective concentration $\left(\mathrm{EC}_{50}\right)$ level of $\mathrm{Ca}^{2+}$ in TRPM4 from 15 to $4 \mu \mathrm{M}[8,74]$, which suggests that the increased activity of PKC helps improve the $\mathrm{Ca}^{2+}$ sensitivity of TRPM4 and resist its desensitization. This effect of PMA disappears when both the readily-phosphorylated amino acid residues, S1145A and S1152A, at the C-terminus of TRPM4 carry mutations [8].

\subsection{4. $\mathrm{CaM}$}

A previous study by Nilius et al. found that dominant-negative mutants of CaM reduce the activation of TRPM4. CaM partially counters the reduction of $\mathrm{Ca}^{2+}$ sensitivity of endogenous TRPM4. Mutations in the C-terminal binding site of CaM can significantly reduce TRPM4 current amplitude and promote faster current decay. This suggests that the $\mathrm{C}$-terminal binding site of $\mathrm{CaM}$ is vital for the $\mathrm{Ca}^{2+}$ sensitivity of TRPM4 [8,75].

The following sections discuss why it is important to understand TRPM4's role in diseases by exploring the activated mechanism of the channel.

\subsection{Inhibitors of TRPM4}

Flufenamic acid is one of the inhibitors of TRPM4 and widely used in research [1]. Originally, according to Winder et al., flufenamic acid was identified in the 1960s as a member of the anthranilic acid-derivative class of nonsteroidal anti-inflammatory drugs (NSAID) due to its anti-inflammatory property, which is able to inhibit the production of prostaglandins. Subsequently, it has been found that flufenamic acid could act as an ion channel regulator that mainly impacts the nonselective cation channels. The TRPM4 channel can be significantly inhibited by flufenamic acid in the range of 4-12 $\mu \mathrm{M}$. However, it affects sodium, potassium, calcium, and chloride channels as well [76].

Glibenclamide is another TRPM4 inhibitor, which can block TRPM4-like currents in sinoatrial node cells completely at a concentration of $100 \mu \mathrm{M}$ [77]. The inhibiting effect of glibenclamide on TRPM4 channel is weaker than that on ATP-dependent $\mathrm{K}^{+}$channels, which are vital therapeutic targets of type II diabetes [78]. Compared to the chemicals above, 9-phenanthrol, which is a tricyclic aromatic compound, inhibits TRPM4 activity specifically $[79,80]$. 


\section{TRPM4 and Cardiovascular Disease}

\subsection{TRPM4 and Arrhythmia}

Arrhythmia is a group of conditions with abnormal frequency of cardiac pulsation and/or rhythm, caused in the origin of heart activity and/or conduction disturbances, such as atrial sinus node dysregulation, excitement outside the sinoatrial node, agitation, slow conduction, and blocked or abnormal channel conduction [81-84]. Arrhythmia is an important class of diseases with respect to cardiovascular risk. The reverse transport of the sodium-calcium exchanger (NCX) on cardiomyocytes is one of the major pathways that leads to intracellular $\mathrm{Ca}^{2+}$ overload [85-89]. The research of Voigt et al. In 2011 demonstrated that increased NCX expression and activity can delay afterdepolarization, which triggers and promotes chronic atrial fibrillation [86,90-92]. Interestingly, the coupling of TRP channels with NCX proteins (TRP-NCX-mediated $\mathrm{Ca}^{2+}$ signaling) is able to disrupt intracellular $\mathrm{Na}^{+}$ and $\mathrm{Ca}^{2+}$ concentration, which produces a sudden accumulation of intracellular $\mathrm{Ca}^{2+}$, especially in the case of TRPC3 [93-95].

It is clear that TRPM4 is highly expressed in atrial cardiomyocytes [1,77]. Being a member of the TRP channel family, it is worth considering whether a coupling between TRPM4 and reverse mode-NCX may induce atrial arrhythmias [12]. In 2009, a TRPM4 mutation was detected in a patient with hereditary heart disease: the glutamate at position 7 was replaced with lysine, which induced progressive cardiac bundle-branch block [96]. This is the first case to closely link TRPM4 mutation to the pathophysiology of human cardiovascular disease $[1,96]$. The researchers subsequently demonstrated that although these mutations did not change the physiological characteristics of TRPM4, the SUMOylation-a post-translational modification to regulate the protein function by combining a member of the small ubiquitin-like modifier (SUMO) family and the target protein-of the mutant protein caused the alternation of TRPM4 protein expression and its current level at the plasma membrane [16-18,97].

However, the link between the function of TRPM4 and cardiac conduction block remains unclear. Perhaps the dysfunction of the voltage-dependent $\mathrm{Na}^{+}$channel takes place, considering that TRPM4 switches on the depolarization of the cell membrane potential, which subsequently injures the cardiac conduction system [52,98,99]. Recently, other studies have also illustrated that TRPM4 mutations are associated with isolated cardiac conduction disease, right bundle-branch block, tachycardia, and Brugada syndrome [17-21].

In summary, the fluctuation of $\mathrm{Na}^{+}$and $\mathrm{Ca}^{2+}$ is involved in the regulation of the cardiac conduction system and is closely linked to the development of arrhythmia. As a result, TRPM4, which is an important $\mathrm{Ca}^{2+}$ regulator, may also be involved in cardiac conduction system diseases.

\subsection{TRPM4 and Cardiac Hypertrophy}

Cardiac hypertrophy is one of powerful adaptive mechanisms of the cardiovascular system, which is mainly manifested by an increase in cell volume and weight [100-102]. Adaptive alteration, which is so-called physiological hypertrophy, occurs to meet the increased demand of blood circulation. Under the physiological condition, the cardiac function can be performed in an orderly manner [93]. However, if it exceeds the range of compensation owing to cardiac pressure or volume overload, such as high levels of angiotensin II (AII), chronic hypertension, valvular dysfunction, myocardial infarction, and even excessive training, the hypertrophy shifts to an irreversible pathology, which induces severe arrhythmia or cardiac failure [22,103-106].

Calcium is indispensable in the excitation-contraction coupling and heart contractility under normal physiological conditions $[87,88]$. In the opinion of Lopea et al. In 1997, intracellular Ca ${ }^{2+}$ levels in the cardiomyocytes of humans with myocardial hypertrophy were sustained at high levels [107], which might be due to the following two methods: First, the activation of the phosphoinositide-specific PLC pathway leads to the generation of inositol 1,4,5-trisphosphate and diacylglycerol (DAG) via the hydrolysis of $\mathrm{PIP}_{2}$, both of which function as secondary messengers mediating the release of $\mathrm{Ca}^{2+}$ 
from the smooth endoplasmic reticulum and sarcoplasmic reticulum [22,108-110]. Second, the nuclear factor of activated $\mathrm{T}$ cells (NFAT), one of the transcription factors regulated by calcium signaling, also takes part in the regulation of decompensated cardiac hypertrophy. CaM activates serine/threonine phosphatase calcineurin $(\mathrm{CN})$, and activated $\mathrm{CN}$ rapidly dephosphorylates the serine-rich region and serine-proline (SP)-repeats in the amino termini of NFAT, resulting in its translocation from the cytoplasm to the nucleus and producing pathological cardiac hypertrophy [111-114]. There is no doubt that $\mathrm{Ca}^{2+}$ plays a significant role in inducing cardiac hypertrophy. Therefore, if the mechanisms that maintain intracellular $\mathrm{Ca}^{2+}$ homeostasis are perturbed, the evolution of the hypertrophic alteration at the stage of compensation and decompensation in the myocardium is affected. Thus, calcium-regulated ion channels act as typical mediators.

TRP channels are important targets in myocardial remodeling because they are capable of transmitting long-term calcium signals [115-117]. Studies have shown that TRPM4 seems to be involved in the occurrence and development of cardiac hypertrophy, in accordance with Demion et al., Kecskés et al., and Guefer et al. [104,118,119]. Indeed, TRPM4 has been shown to play a role in cardiac hypertrophy by the construction of a typical model that mimics the ventricular hypertrophic alteration in spontaneously hypertensive rats (SHRs) [120]. Changes in TRPM4 current and mRNA levels are detectable in SHRs. Compared with WKY rats (control group), the expression levels of TRPM4 mRNA in SHRs were almost 50-fold.

Although a significant level of TRPM4 current exists in SHRs, it is quite challenging to find it in WKY rats even by facilitating the TRPM4 current with application of PKC. TRPM4 properties can be monitored by the Patch-Clamp measurement to illustrate the existence of a nonselective cation channel in ventricular cardiomyocytes isolated from SHRs. Thus, TRPM4 is crucial during the process of ventricular remodeling [22,120].

TRPM4 is a negative regulator of cardiac hypertrophy induced by angiotensin II (AII) stimulation [104]. In this previous study, the researchers selectively removed the exons 15 and 16 from TRPM4 for establishing a cardiac-specific TRPM4-knockout mouse line (TRPM4 ${ }^{\mathrm{cKO}}$ ). They intended to compare cardiac hypertrophic changes between TRPM4 ${ }^{\mathrm{CKO}}$ mice and wild-type mice (littermate controls; TRPM4 ${ }^{+/+}$) under AII stimulation. Their results showed significantly higher cardiac hypertrophy at the morphological level in TRPM $4^{\mathrm{cKO}}$ mice compared with the wild-type mice, including increased heart size and weight. In addition, high levels of hypertrophy-related genes such as atrial natriuretic peptide (ANP), $\alpha$-actin, and Rcan 1 were detected in the TRPM4 $4^{\mathrm{cKO}}$ mice.

TRPM4 deficiency increases the hypertrophic response to chronic AII in cultured neonatal myocytes. Increased intracellular $\mathrm{Ca}^{2+}$ concentration in isolated ventricular cardiomyocytes of TRPM4 $4^{\mathrm{cKO}}$ mice after AII stimulation reconfirmed that TRPM4 is a key regulator of intracellular $\mathrm{Ca}^{2+}$. There was also a significant rise in $\mathrm{CN}$ phosphatase activity in the hearts of TRPM4 $4^{\mathrm{cKO}}$ mice following AII treatment. In these mice, Rcan1 mRNA, which is a reporter of the calcineurin-NFAT activation typical in cardiac hypertrophy, is overexpressed. Additionally, store-operated calcium entry (SOCE), which is helpful in promoting intracellular $\mathrm{Ca}^{2+}$ collection from the extracellular environment, has been regarded as having an important role in mediating cardiac hypertrophy $[104,117,121]$. The study of Kecskés et al. showed that AngII-mediated SOCE was increased in Trpm $4^{-1-}$ myocytes [104]. It means that TRPM4 is related to modulation of the $\mathrm{Ca}^{2+}$ influx through SOCE to induce pathological hypertrophy $[104,117,121]$

TRPM4 is important for the beneficial cardiac remodeling induced by endurance training, and the role of TRPM4 in physiological and pathological cardiac hypertrophy has also been studied [118]. In TRPM4 $4^{+/+}$mice, enhanced cardiac function in response to endurance training was observed. In contrast, a high number of apoptotic DNA fragments are detectable in TRPM4 ${ }^{-/-}$mice after endurance training. This illustrates that TRPM4 can obstruct the progress from adaptive hypertrophy to irreversible cardiac remodeling. In the pathological cardiac hypertrophy, $\mathrm{Ca}^{2+}$ entry via SOCs causes activation of the calcineurin-NFAT pathway. The TRPM4 channel inhibits the SOCs and thus prevents pathological remodeling [118]. 
The link between TRPM4 and arrhythmia, wherein 9-phenanthrol can inhibit TRPM4 and can shorten the duration of action potentials (APs), has been confirmed previously, which implies that TRPM4 can delay AP repolarization [119]. It has been hypothesized that TRPM4 is implicated in the prolongation of AP duration, which may be present in the hypertrophied heart, but has not been verified to date [122-124].

Thus, TRPM4 is an essential regulator of the hypertrophic alteration and is likely to supply a novel direction for the treatment of cardiovascular diseases caused by cardiac hypertrophy [22,122].

\subsection{TRPM4 and Myocardial IRI}

Ischemic heart diseases (IHDs) have become the most frequently reported threat to human health $[125,126]$. Myocardial ischemia originates owing to a reduction in coronary blood flow, which may result in an imbalance between myocardial supply and demand of oxygen. Typical symptoms include chest pain, chest discomfort, weakness or dyspnea after exercise, and mental stimulation or overeating, which are detrimental to the quality of life. Restoring the blood flow is an effective therapeutic strategy to treat ischemia, as achieved through thrombolysis, coronary artery bypass graft, and percutaneous coronary intervention. However, secondary injuries after recanalization are risk factors to IHD patients, such as contractile dysfunction, arrhythmia, and sudden death, which are also known as myocardial IRI [127-129].

The mechanism underlying myocardial ischemia-reperfusion injury (IRI) is complex [130-132]. At the onset of ischemia, ATP decreases progressively, which subsequently causes a dysfunction of ion pumps, leading to the accumulation of intracellular $\mathrm{Ca}^{2+}$, especially in the mitochondria. This promotes the depletion of ATP with increased $\mathrm{Ca}^{2+}$, leading to cell death. With the return of blood flow, even if it is conducive to the recovery of ATP, a large burst of $\mathrm{Ca}^{2+}$ and reactive oxygen species in the mitochondria occurs at the onset of reperfusion, which opens the mitochondrial permeability transition pore and causes further myocardial damage. Thus, reduced ATP and disrupted calcium metabolism eventually lead to myocardial IRI. It has also been identified that $\mathrm{Ca}^{2+}$ increase and ATP depletion are involved in the activation of TRPM4, and a link between TRPM4 and myocardial IRI has been reported [36,130-134].

Inhibition of TRPM4 with 9-phenanthrol (9-Phe) has been shown to confer cardioprotective effects against IRI in the rat heart [24]. In the Langendorff-perfused rat heart, the TRPM4 inhibitor 9-Phe produced a dramatic recovery of the damaged left ventricular contractile function caused by experimental IRI. Furthermore, 9-Phe treatment could effectively resist the ventricular fibrillation induced by IRI. This showed that damaged cardiac contractile function caused by IRI could be rescued through the inhibition of TRPM4, which may confer cardioprotection mainly via an antiarrhythmic effect. After IRI, the infarcted area of myocardium was smaller in the rats treated with 9-Phe, which further elaborated that regulation of TRPM4 is important in reversing the myocardial damage induced by IRI [24].

The relationship between TRPM4 and myocardial IRI has been explored more deeply in vitro as well [23]. In rat ventricular cardiomyocytes $\mathrm{H} 9 \mathrm{c2}$, 9-Phe treatment prevented cellular damage caused by two types of IRI models: one being reactive oxygen species stimulation (ROS) by hydrogen peroxide $\left(\mathrm{H}_{2} \mathrm{O}_{2}\right)$ exposure, and the other being hypoxia/reoxygenation $(\mathrm{H} / \mathrm{R})$ induction. Moreover, the viability of cardiomyocytes with the TRPM4 knocked down through small interfering RNA (siRNA) transfection was significantly higher than that of the nontransfection group following ROS damage and $\mathrm{H} / \mathrm{R}$ induction. It can also be suggested that inhibition of TRPM4 protects cardiomyocytes against IRI both in vivo and in vitro, and 9-Phe treatment confers remarkable cardioprotection against oxidative stress injury. Therefore, inhibiting TRPM4 might be promising in treating myocardial IRI for IHD patients [23].

TRPM4 is closely related to intracellular $\mathrm{Ca}^{2+}$ dynamic equilibrium, and the mechanism of intracellular $\mathrm{Ca}^{2+}$ overload-induced IRI has already been elucidated $[8,116,122,135]$. Therefore, the role 
of inhibiting TRPM4 in ameliorating an abrupt increase in intracellular $\mathrm{Ca}^{2+}$ during myocardial IRI is being explored.

\subsection{TRPM4 and Endothelial Cell Injury and Apoptosis}

Endothelial injury is the risk factor and may cause a series of cardiovascular system disorders $[136,137]$. Due to the research conducted by Gerzanich et al., Becerra et al., and Ding et al., the expression of TRPM4 could be upregulated when the vascular endothelium is damaged under a variety of pathological conditions. For example, TRPM4 expression levels increase by more than $33 \%$ in endothelial cells damaged owing to a high-salt diet [138-141]. Moreover, the expression of TRPM4 in both protein and mRNA forms increases in human umbilical vein endothelial cells under hypoxic and ischemic conditions [10,142]. It has also been shown that TRPM4 is involved in lipopolysaccharide-induced vascular endothelial injury [139]. Thus, inhibiting the expression or activity of TRPM4 via 9-Phe and glibenclamide can effectively protect vascular endothelial cells against lipopolysaccharide-induced damage.

In a lipopolysaccharide-treated group, more than $40 \%$ of the endothelial cells were apoptotic, whereas the apoptosis in the TRPM4-inhihition group reduced significantly [139]. Lipopolysaccharide induces endothelial cell death because it promotes a rise in intracellular ROS [143]. Furthermore, the expression of TRPM4 is significantly upregulated upon treatment with exogenous $\operatorname{ROS}\left(\mathrm{H}_{2} \mathrm{O}_{2}\right)$, which results in endothelial cell apoptosis. However, this could be reversed through the inhibition of TRPM4 activity with 9-Phe [138]. Thus, it is implied that the involvement of TRPM4 in endothelial injury is also mediated by ROS $[131,133,134,144]$.

It is clear that under the influence of various vascular injury factors, the upregulation of TRPM4 in vascular endothelial cells produces complete or maximal depolarization, resulting in the continuous influx of sodium ions [137-139]. Soon afterwards, the rise of intracellular $\mathrm{Na}^{+}$and $\mathrm{Cl}^{-}$is able to cause enlargement of osmotic pressure, which drives the influx of $\mathrm{H}_{2} \mathrm{O}$, inducing cell swelling or rupture [140].

\section{Conclusions}

Overall, TRPM4 is an important nonselective cation channel involved in cellular calcium regulation. a majority of cardiovascular diseases are closely related to calcium homeostasis. As the research on TRPM4 progresses, more functions will be recognized and intrinsic links between TRPM4 and the development of cardiovascular diseases may be discovered.

Author Contributions: Conceptualization: C.W. and K.T.; investigation: C.W. and K.T.; writing-original draft preparation: C.W.; writing—review and editing: K.N. and K.T.; supervision: K.N. and K.T.; project administration: K.T.; funding acquisition: K.T.

Funding: This study was supported by Grant-in-Aid for Scientific Research (C), No. 16K01356.

Acknowledgments: This study was supported by Grant-in-Aid for Scientific Research (C), No. 16K01356.

Conflicts of Interest: The authors declare no conflict of interest.

\section{References}

1. Guinamard, R.; Demion, M.; Launay, P. Physiological roles of the trpm 4 channel extracted from background currents. Physiology 2010, 25, 155-164. [CrossRef] [PubMed]

2. Launay, P.; Fleig, A.; Perraud, A.L.; Scharenberg, A.M.; Penner, R.; Kinet, J.P. Trpm4 is a ca2+-activated nonselective cation channel mediating cell membrane depolarization. Cell 2002, 109, 397-407. [CrossRef]

3. Song, M.Y.; Yuan, J.X. Introduction to trp channels: Structure, function, and regulation. Adv. Exp. Med. Biol. 2010, 661, 99-108. [PubMed]

4. Fleig, A.; Penner, R. The trpm ion channel subfamily: Molecular, biophysical and functional features. Trends Pharmacol. Sci. 2004, 25, 633-639. [CrossRef] [PubMed] 
5. Mathar, I.; Jacobs, G.; Kecskes, M.; Menigoz, A.; Philippaert, K.; Vennekens, R. Trpm4. Handb. Exp. Pharmacol. 2014, 222, 461-487. [PubMed]

6. Nilius, B.; Mahieu, F.; Prenen, J.; Janssens, A.; Owsianik, G.; Vennekens, R.; Voets, T. The Ca ${ }^{2+}$-activated cation channel trpm4 is regulated by phosphatidylinositol 4, 5-biphosphate. EMBO J. 2006, 25, 467-478. [CrossRef] [PubMed]

7. Zhang, Z.; Okawa, H.; Wang, Y.; Liman, E.R. Phosphatidylinositol 4, 5-bisphosphate rescues trpm4 channels from desensitization. J. Biol. Chem. 2005, 280, 39185-39192. [CrossRef] [PubMed]

8. Nilius, B.; Prenen, J.; Tang, J.; Wang, C.; Owsianik, G.; Janssens, A.; Voets, T.; Zhu, M.X. Regulation of the $\mathrm{Ca}^{2+}$ sensitivity of the nonselective cation channel trpm4. J. Biol. Chem. 2005, 280, 6423-6433. [CrossRef] [PubMed]

9. Nilius, B.; Vennekens, R. From cardiac cation channels to the molecular dissection of the transient receptor potential channel trpm4. Pflugers Arch. 2006, 453, 313-321. [CrossRef] [PubMed]

10. Vennekens, R.; Nilius, B. Insights into trpm4 function, regulation and physiological role. Handb. Exp. Pharmacol. 2007, 179, 269-285.

11. Earley, S.; Straub, S.V.; Brayden, J.E. Protein kinase c regulates vascular myogenic tone through activation of trpm4. Am. J. Physiol. Heart Circ. Physiol. 2007, 292, H2613-H2622. [CrossRef] [PubMed]

12. Watanabe, H.; Murakami, M.; Ohba, T.; Ono, K.; Ito, H. The pathological role of transient receptor potential channels in heart disease. Circ. J. 2009, 73, 419-427. [CrossRef] [PubMed]

13. Kaneko, Y.; Szallasi, A. Transient receptor potential (trp) channels: a clinical perspective. Br. J. Pharmacol. 2014, 171, 2474-2507. [CrossRef] [PubMed]

14. Nilius, B. Trp channels in disease. Biochim. Biophys. Acta 2007, 1772, 805-812. [CrossRef] [PubMed]

15. Cho, C.H.; Lee, Y.S.; Kim, E.; Hwang, E.M.; Park, J.Y. Physiological functions of the trpm 4 channels via protein interactions. BMB Rep. 2015, 48, 1-5. [CrossRef] [PubMed]

16. Voolstra, O.; Huber, A. Post-translational modifications of trp channels. Cells 2014, 3, 258-287. [CrossRef] [PubMed]

17. Guinamard, R.; Bouvagnet, P.; Hof, T.; Liu, H.; Simard, C.; Salle, L. Trpm4 in cardiac electrical activity. Cardiovasc. Res. 2015, 108, 21-30. [CrossRef] [PubMed]

18. Liu, H.; El Zein, L.; Kruse, M.; Guinamard, R.; Beckmann, A.; Bozio, A.; Kurtbay, G.; Megarbane, A.; Ohmert, I.; Blaysat, G.; et al. Gain-of-function mutations in trpm4 cause autosomal dominant isolated cardiac conduction disease. Circ. Cardiovasc. Genet. 2010, 3, 374-385. [CrossRef] [PubMed]

19. Stallmeyer, B.; Zumhagen, S.; Denjoy, I.; Duthoit, G.; Hebert, J.L.; Ferrer, X.; Maugenre, S.; Schmitz, W.; Kirchhefer, U.; Schulze-Bahr, E.; et al. Mutational spectrum in the $\mathrm{Ca}\left({ }^{2+}\right)$-Activated cation channel gene trpm4 in patients with cardiac conductance disturbances. Hum. Mutat. 2012, 33, 109-117. [CrossRef] [PubMed]

20. Liu, H.; Chatel, S.; Simard, C.; Syam, N.; Salle, L.; Probst, V.; Morel, J.; Millat, G.; Lopez, M.; Abriel, H.; et al. Molecular genetics and functional anomalies in a series of 248 brugada cases with 11 mutations in the trpm4 channel. PLoS ONE 2013, 8. [CrossRef] [PubMed]

21. Duthoit, G.; Fressart, V.; Hidden-Lucet, F.; Simon, F.; Kattygnarath, D.; Charron, P.; Himbert, C.; Aouate, P.; Guicheney, P.; Lecarpentier, Y.; et al. Brugada ecg pattern: a physiopathological prospective study based on clinical, electrophysiological, angiographic, and genetic findings. Front. Physiol. 2012, 3. [CrossRef] [PubMed]

22. Guinamard, R.; Bois, P. Involvement of transient receptor potential proteins in cardiac hypertrophy. Biochim. Biophys. Acta 2007, 1772, 885-894. [CrossRef] [PubMed]

23. Piao, H.; Takahashi, K.; Yamaguchi, Y.; Wang, C.; Liu, K.; Naruse, K. Transient receptor potential melastatin-4 is involved in hypoxia-reoxygenation injury in the cardiomyocytes. PLoS ONE 2015, 10. [CrossRef] [PubMed]

24. Wang, J.; Takahashi, K.; Piao, H.; Qu, P.; Naruse, K. 9-phenanthrol, a trpm4 inhibitor, protects isolated rat hearts from ischemia-reperfusion injury. PLoS ONE 2013, 8. [CrossRef] [PubMed]

25. Minke, B.; Wu, C.; Pak, W.L. Induction of photoreceptor voltage noise in the dark in drosophila mutant. Nature 1975, 258, 84-87. [CrossRef] [PubMed]

26. Li, M.; Yu, Y.; Yang, J. Structural biology of trp channels. Adv. Exp. Med. Biol. 2011, 704, 1-23. [PubMed]

27. Peacock, M. Calcium metabolism in health and disease. Clin. J. Am. Soc. Nephrol. 2010, 5 (Suppl. 1), S23-S30. [CrossRef] [PubMed] 
28. Zaichick, S.V.; McGrath, K.M.; Caraveo, G. The role of $\left.\mathrm{Ca}^{2+}\right)$ signaling in parkinson's disease. Dis. Model Mech. 2017, 10, 519-535. [CrossRef] [PubMed]

29. Bronner, F. Extracellular and intracellular regulation of calcium homeostasis. Sci. World J. 2001, 1, 919-925. [CrossRef] [PubMed]

30. Hennings, H.; Holbrook, K.A. Calcium regulation of cell-cell contact and differentiation of epidermal cells in culture. an ultrastructural study. Exp. Cell Res. 1983, 143, 127-142. [CrossRef]

31. Kopic, S.; Geibel, J.P. Gastric acid, calcium absorption, and their impact on bone health. Physiol. Rev. 2013, 93, 189-268. [CrossRef] [PubMed]

32. Campbell, A.K. Calcium as an intracellular regulator. Proc. Nutr. Soc. 1990, 49, 51-56. [CrossRef] [PubMed]

33. Christakos, S.; Lieben, L.; Masuyama, R.; Carmeliet, G. Vitamin d endocrine system and the intestine. Bonekey Rep. 2014, 3. [CrossRef] [PubMed]

34. Brown, S.J.; Ruppe, M.D.; Tabatabai, L.S. The parathyroid gland and heart disease. Methodist. Debakey Cardiovasc. J. 2017, 13, 49-54. [CrossRef] [PubMed]

35. Castaldo, P.; Macri, M.L.; Lariccia, V.; Matteucci, A.; Maiolino, M.; Gratteri, S.; Amoroso, S.; Magi, S. $\mathrm{Na}\left({ }^{+}\right) / \mathrm{Ca}\left({ }^{2+}\right)$ exchanger 1 inhibition abolishes ischemic tolerance induced by ischemic preconditioning in different cardiac models. Eur. J. Pharmacol. 2017, 794, 246-256. [CrossRef] [PubMed]

36. Murphy, E.; Steenbergen, C. Mechanisms underlying acute protection from cardiac ischemia-reperfusion injury. Physiol. Rev. 2008, 88, 581-609. [CrossRef] [PubMed]

37. Potz, B.A.; Sabe, A.A.; Abid, M.R.; Sellke, F.W. Calpains and coronary vascular disease. Circ. J. 2016, 80, 4-10. [CrossRef] [PubMed]

38. Joseph, L.C.; Subramanyam, P.; Radlicz, C.; Trent, C.M.; Iyer, V.; Colecraft, H.M.; Morrow, J.P. Mitochondrial oxidative stress during cardiac lipid overload causes intracellular calcium leak and arrhythmia. Heart Rhythm 2016, 13, 1699-1706. [CrossRef] [PubMed]

39. Skioldebrand, E.; Lundqvist, A.; Bjorklund, U.; Sandstedt, M.; Lindahl, A.; Hansson, E.; Hulten, L.M. Inflammatory activation of human cardiac fibroblasts leads to altered calcium signaling, decreased connexin 43 expression and increased glutamate secretion. Heliyon 2017, 3. [CrossRef] [PubMed]

40. Runte, K.E.; Bell, S.P.; Selby, D.E.; Haussler, T.N.; Ashikaga, T.; LeWinter, M.M.; Palmer, B.M.; Meyer, M. Relaxation and the role of calcium in isolated contracting myocardium from patients with hypertensive heart disease and heart failure with preserved ejection fraction. Circ. Heart Fail. 2017, 10. [CrossRef] [PubMed]

41. Ramsey, I.S.; Delling, M.; Clapham, D.E. an introduction to trp channels. Annu. Rev.Physiol. 2006, 68, 619-647. [CrossRef] [PubMed]

42. Prevarskaya, N.; Skryma, R.; Bidaux, G.; Flourakis, M.; Shuba, Y. Ion channels in death and differentiation of prostate cancer cells. Cell Death Differ. 2007, 14, 1295-1304. [CrossRef] [PubMed]

43. Ciardo, M.G.; Ferrer-Montiel, A. Lipids as central modulators of sensory trp channels. Biochim. Biophys. Acta 2017, 1859, 1615-1628. [CrossRef] [PubMed]

44. Gees, M.; Colsoul, B.; Nilius, B. The role of transient receptor potential cation channels in $\mathrm{Ca}^{2+}$ signaling. Cold Spring Harb. Perspect. Biol. 2010, 2. [CrossRef] [PubMed]

45. Clapham, D.E.; Runnels, L.W.; Strubing, C. The trp ion channel family. Nat. Rev. Neurosci. 2001, 2, $387-396$. [CrossRef] [PubMed]

46. Nilius, B.; Owsianik, G. The transient receptor potential family of ion channels. Genome Biol. $2011,12$. [CrossRef] [PubMed]

47. Bouron, A.; Kiselyov, K.; Oberwinkler, J. Permeation, regulation and control of expression of trp channels by trace metal ions. Pflugers Arch. 2015, 467, 1143-1164. [CrossRef] [PubMed]

48. Gaudet, R. Trp channels entering the structural era. J. Physiol. 2008, 586, 3565-3575. [CrossRef] [PubMed]

49. Dimke, H.; Hoenderop, J.G.; Bindels, R.J. Molecular basis of epithelial $\mathrm{Ca}^{2+}$ and $\mathrm{Mg}^{2+}$ transport: Insights from the trp channel family. J. Physiol. 2011, 589, 1535-1542. [CrossRef] [PubMed]

50. Zheng, J. Molecular mechanism of trp channels. Compr. Physiol. 2013, 3, 221-242. [PubMed]

51. Nilius, B.; Prenen, J.; Droogmans, G.; Voets, T.; Vennekens, R.; Freichel, M.; Wissenbach, U.; Flockerzi, V. Voltage dependence of the $\mathrm{Ca}^{2+}$-activated cation channel trpm4. J. Biol. Chem. 2003, 278, 30813-30820. [CrossRef] [PubMed]

52. Nilius, B.; Prenen, J.; Janssens, A.; Owsianik, G.; Wang, C.; Zhu, M.X.; Voets, T. The selectivity filter of the cation channel trpm4. J. Biol. Chem. 2005, 280, 22899-22906. [CrossRef] [PubMed] 
53. Dutta Banik, D.; Martin, L.E.; Freichel, M.; Torregrossa, A.M.; Medler, K.F. Trpm 4 and trpm5 are both required for normal signaling in taste receptor cells. Proc. Natl. Acad. Sci. USA 2018, 115, E772-E781. [CrossRef] [PubMed]

54. Talavera, K.; Yasumatsu, K.; Voets, T.; Droogmans, G.; Shigemura, N.; Ninomiya, Y.; Margolskee, R.F.; Nilius, B. Heat activation of trpm5 underlies thermal sensitivity of sweet taste. Nature 2005, 438, 1022-1025. [CrossRef] [PubMed]

55. Voets, T.; Droogmans, G.; Wissenbach, U.; Janssens, A.; Flockerzi, V.; Nilius, B. The principle of temperature-dependent gating in cold- and heat-sensitive trp channels. Nature 2004, 430, 748-754. [CrossRef] [PubMed]

56. Liman, E.R. The $\mathrm{Ca}\left({ }^{2+}\right)$-activated trp channels: Trpm 4 and trpm5. Front. Neurosci. 2007. [CrossRef]

57. Fonfria, E.; Murdock, P.R.; Cusdin, F.S.; Benham, C.D.; Kelsell, R.E.; McNulty, S. Tissue distribution profiles of the human trpm cation channel family. J. Recept. Signal Transduct. Res. 2006, 26, 159-178. [CrossRef] [PubMed]

58. Simard, C.; Hof, T.; Keddache, Z.; Launay, P.; Guinamard, R. The trpm4 non-selective cation channel contributes to the mammalian atrial action potential. J. Mol. Cell. Cardiol. 2013, 59, 11-19. [CrossRef] [PubMed]

59. Demir, T.; Yumrutas, O.; Cengiz, B.; Demiryurek, S.; Unverdi, H.; Kaplan, D.S.; Bayraktar, R.; Ozkul, N.; Bagci, C. Evaluation of trpm (transient receptor potential melastatin) genes expressions in myocardial ischemia and reperfusion. Mol. Biol. Rep. 2014, 41, 2845-2849. [CrossRef] [PubMed]

60. Guo, J.; She, J.; Zeng, W.; Chen, Q.; Bai, X.C.; Jiang, Y. Structures of the calcium-activated, non-selective cation channel trpm4. Nature 2017, 552, 205-209. [CrossRef] [PubMed]

61. Winkler, P.A.; Huang, Y.; Sun, W.; Du, J.; Lu, W. Electron cryo-microscopy structure of a human trpm4 channel. Nature 2017, 552, 200-204. [CrossRef] [PubMed]

62. Autzen, H.E.; Myasnikov, A.G.; Campbell, M.G.; Asarnow, D.; Julius, D.; Cheng, Y. Structure of the human trpm4 ion channel in a lipid nanodisc. Science 2018, 359, 228-232. [CrossRef] [PubMed]

63. Watschinger, K.; Horak, S.B.; Schulze, K.; Obermair, G.J.; Wild, C.; Koschak, A.; Sinnegger-Brauns, M.J.; Tampe, R.; Striessnig, J. Functional properties and modulation of extracellular epitope-tagged Ca(v)2.1 voltage-gated calcium channels. Channels 2008, 2, 461-473. [CrossRef] [PubMed]

64. Hammond, G.R.; Dove, S.K.; Nicol, A.; Pinxteren, J.A.; Zicha, D.; Schiavo, G. Elimination of plasma membrane phosphatidylinositol (4,5)-bisphosphate is required for exocytosis from mast cells. J. Cell Sci. 2006, 119, 2084-2094. [CrossRef] [PubMed]

65. Bulley, S.J.; Clarke, J.H.; Droubi, A.; Giudici, M.L.; Irvine, R.F. Exploring phosphatidylinositol 5-phosphate 4-kinase function. Adv. Biol. Regul. 2015, 57, 193-202. [CrossRef] [PubMed]

66. Rodriguez-Menchaca, A.A.; Adney, S.K.; Zhou, L.; Logothetis, D.E. Dual regulation of voltage-sensitive ion channels by pip(2). Front. Pharmacol. 2012, 3. [CrossRef] [PubMed]

67. Macmillan, D.; McCarron, J.G. The phospholipase c inhibitor u-73122 inhibits $\mathrm{Ca}\left({ }^{2+}\right)$ release from the intracellular sarcoplasmic reticulum $\mathrm{Ca}\left({ }^{2+}\right)$ store by inhibiting $\mathrm{Ca}\left({ }^{2+}\right)$ pumps in smooth muscle. Br. J. Pharmacol. 2010, 160, 1295-1301. [CrossRef] [PubMed]

68. Rohacs, T.; Lopes, C.M.; Michailidis, I.; Logothetis, D.E. Pi(4,5)p2 regulates the activation and desensitization of trpm8 channels through the trp domain. Nat. Neurosci. 2005, 8, 626-634. [CrossRef] [PubMed]

69. Earley, S. Trpm4 channels in smooth muscle function. Pflugers Arch. 2013, 465, 1223-1231. [CrossRef] [PubMed]

70. Liu, D.; Liman, E.R. Intracellular $\mathrm{Ca}^{2+}$ and the phospholipid pip2 regulate the taste transduction ion channel trpm5. Proc. Natl. Acad. Sci. USA 2003, 100, 15160-15165. [CrossRef] [PubMed]

71. Bousova, K.; Jirku, M.; Bumba, L.; Bednarova, L.; Sulc, M.; Franek, M.; Vyklicky, L.; Vondrasek, J.; Teisinger, J. Pip2 and pip3 interact with n-terminus region of trpm4 channel. Biophys. Chem. 2015, 205, 24-32. [CrossRef] [PubMed]

72. Orelle, C.; Dalmas, O.; Gros, P.; Di Pietro, A.; Jault, J.M. The conserved glutamate residue adjacent to the walker-b motif is the catalytic base for atp hydrolysis in the atp-binding cassette transporter bmra. J. Biol. Chem. 2003, 278, 47002-47008. [CrossRef] [PubMed]

73. Ren, X.Q.; Furukawa, T.; Haraguchi, M.; Sumizawa, T.; Aoki, S.; Kobayashi, M.; Akiyama, S. Function of the abc signature sequences in the human multidrug resistance protein 1. Mol. Pharmacol. 2004, 65, 1536-1542. [CrossRef] [PubMed] 
74. Yao, X.; Kwan, H.Y.; Huang, Y. Regulation of trp channels by phosphorylation. Neurosignals 2005, 14, $273-280$. [CrossRef] [PubMed]

75. Bousova, K.; Herman, P.; Vecer, J.; Bednarova, L.; Monincova, L.; Majer, P.; Vyklicky, L.; Vondrasek, J.; Teisinger, J. Shared cam- and s100a1-binding epitopes in the distal trpm $4 \mathrm{n}$ terminus. FEBS J. 2018, 285, 599-613. [CrossRef] [PubMed]

76. Guinamard, R.; Simard, C.; Del Negro, C. Flufenamic acid as an ion channel modulator. Pharmacol. Ther. 2013, 138, 272-284. [CrossRef] [PubMed]

77. Demion, M.; Bois, P.; Launay, P.; Guinamard, R. Trpm4, a $\mathrm{Ca}^{2+}$-activated nonselective cation channel in mouse sino-atrial node cells. Cardiovasc. Res. 2007, 73, 531-538. [CrossRef] [PubMed]

78. Ozhathil, L.C.; Delalande, C.; Bianchi, B.; Nemeth, G.; Kappel, S.; Thomet, U.; Ross-Kaschitza, D.; Simonin, C.; Rubin, M.; Gertsch, J.; et al. Identification of potent and selective small molecule inhibitors of the cation channel trpm4. Br. J. Pharmacol. 2018, 175, 2504-2519. [CrossRef] [PubMed]

79. Grand, T.; Demion, M.; Norez, C.; Mettey, Y.; Launay, P.; Becq, F.; Bois, P.; Guinamard, R. 9-phenanthrol inhibits human trpm 4 but not trpm5 cationic channels. Br. J. Pharmacol. 2008, 153, 1697-1705. [CrossRef] [PubMed]

80. Burris, S.K.; Wang, Q.; Bulley, S.; Neeb, Z.P.; Jaggar, J.H. 9-phenanthrol inhibits recombinant and arterial myocyte tmem16a channels. Br. J. Pharmacol. 2015, 172, 2459-2468. [CrossRef] [PubMed]

81. Bethge, K.P. Classification of arrhythmias. J. Cardiovasc. Pharmacol. 1991, 17 (Suppl. 6), S13-S19. [CrossRef] [PubMed]

82. Fu, D.G. Cardiac arrhythmias: Diagnosis, symptoms, and treatments. Cell Biochem. Biophys. 2015, 73, $291-296$. [CrossRef] [PubMed]

83. John, R.M.; Tedrow, U.B.; Koplan, B.A.; Albert, C.M.; Epstein, L.M.; Sweeney, M.O.; Miller, A.L.; Michaud, G.F.; Stevenson, W.G. Ventricular arrhythmias and sudden cardiac death. Lancet 2012, 380, 1520-1529. [CrossRef]

84. Grace, A.A.; Roden, D.M. Systems biology and cardiac arrhythmias. Lancet 2012, 380, 1498-1508. [CrossRef]

85. Conway, S.J.; Koushik, S.V. Cardiac sodium-calcium exchanger: a double-edged sword. Cardiovasc. Res. 2001, 51, 194-197. [CrossRef]

86. Blaustein, M.P.; Lederer, W.J. Sodium/calcium exchange: Its physiological implications. Physiol. Rev. 1999, 79, 763-854. [CrossRef] [PubMed]

87. Goldhaber, J.I.; Philipson, K.D. Cardiac sodium-calcium exchange and efficient excitation-contraction coupling: Implications for heart disease. Adv. Exp. Med. Biol. 2013, 961, 355-364. [PubMed]

88. Ottolia, M.; Torres, N.; Bridge, J.H.; Philipson, K.D.; Goldhaber, J.I. Na/ca exchange and contraction of the heart. J. Mol. Cell. Cardiol. 2013, 61, 28-33. [CrossRef] [PubMed]

89. Giladi, M.; Shor, R.; Lisnyansky, M.; Khananshvili, D. Structure-functional basis of ion transport in sodium-calcium exchanger (ncx) proteins. Int. J. Mol. Sci. 2016, 17. [CrossRef] [PubMed]

90. Herrmann, S.; Lipp, P.; Wiesen, K.; Stieber, J.; Nguyen, H.; Kaiser, E.; Ludwig, A. The cardiac sodium-calcium exchanger ncx 1 is a key player in the initiation and maintenance of a stable heart rhythm. Cardiovasc. Res. 2013, 99, 780-788. [CrossRef] [PubMed]

91. Voigt, N.; Li, N.; Wang, Q.; Wang, W.; Trafford, A.W.; Abu-Taha, I.; Sun, Q.; Wieland, T.; Ravens, U.; Nattel, S.; et al. Enhanced sarcoplasmic reticulum $\mathrm{Ca}^{2+}$ leak and increased $\mathrm{Na}+-\mathrm{Ca}^{2+}$ exchanger function underlie delayed afterdepolarizations in patients with chronic atrial fibrillation. Circulation 2012, 125, 2059-2070. [CrossRef] [PubMed]

92. Dobrev, D.; Nattel, S. Calcium handling abnormalities in atrial fibrillation as a target for innovative therapeutics. J. Cardiovasc. Pharmacol. 2008, 52, 293-299. [CrossRef] [PubMed]

93. Firth, A.L.; Remillard, C.V.; Yuan, J.X. Trp channels in hypertension. Biochim. Biophys. Acta 2007, 1772, 895-906. [CrossRef] [PubMed]

94. Rosker, C.; Graziani, A.; Lukas, M.; Eder, P.; Zhu, M.X.; Romanin, C.; Groschner, K. Ca $\left({ }^{2+}\right)$ signaling by trpc3 involves $\left.\mathrm{Na}^{+}\right)$entry and local coupling to the $\mathrm{Na}\left({ }^{+}\right) / \mathrm{Ca}\left({ }^{2+}\right)$ exchanger. J. Biol. Chem. 2004, 279, 13696-13704. [CrossRef] [PubMed]

95. Doleschal, B.; Primessnig, U.; Wolkart, G.; Wolf, S.; Schernthaner, M.; Lichtenegger, M.; Glasnov, T.N.; Kappe, C.O.; Mayer, B.; Antoons, G.; et al. Trpc3 contributes to regulation of cardiac contractility and arrhythmogenesis by dynamic interaction with ncx1. Cardiovasc. Res. 2015, 106, 163-173. [CrossRef] [PubMed] 
96. Kruse, M.; Schulze-Bahr, E.; Corfield, V.; Beckmann, A.; Stallmeyer, B.; Kurtbay, G.; Ohmert, I.; Brink, P.; Pongs, O. Impaired endocytosis of the ion channel trpm 4 is associated with human progressive familial heart block type I. J. Clin. Investig. 2009, 119, 2737-2744. [CrossRef] [PubMed]

97. Luo, J.; Ashikaga, E.; Rubin, P.P.; Heimann, M.J.; Hildick, K.L.; Bishop, P.; Girach, F.; Josa-Prado, F.; Tang, L.T.; Carmichael, R.E.; et al. Receptor trafficking and the regulation of synaptic plasticity by sumo. Neuromol. Med. 2013, 15, 692-706. [CrossRef] [PubMed]

98. Irvine, L.A.; Jafri, M.S.; Winslow, R.L. Cardiac sodium channel markov model with temperature dependence and recovery from inactivation. Biophys. J. 1999, 76, 1868-1885. [CrossRef]

99. Raman, I.M.; Bean, B.P. Inactivation and recovery of sodium currents in cerebellar purkinje neurons: Evidence for two mechanisms. Biophys. J. 2001, 80, 729-737. [CrossRef]

100. Swynghedauw, B. Molecular mechanisms of myocardial remodeling. Physiol. Rev. 1999, 79, $215-262$. [CrossRef] [PubMed]

101. Wilde, A.A.; Brugada, R. Phenotypical manifestations of mutations in the genes encoding subunits of the cardiac sodium channel. Circ. Res. 2011, 108, 884-897. [CrossRef] [PubMed]

102. Frey, N.; Katus, H.A.; Olson, E.N.; Hill, J.A. Hypertrophy of the heart: a new therapeutic target? Circulation 2004, 109, 1580-1589. [CrossRef] [PubMed]

103. McMullen, J.R.; Jennings, G.L. Differences between pathological and physiological cardiac hypertrophy: Novel therapeutic strategies to treat heart failure. Clin. Exp. Pharmacol. Physiol. 2007, 34, 255-262. [CrossRef] [PubMed]

104. Kecskes, M.; Jacobs, G.; Kerselaers, S.; Syam, N.; Menigoz, A.; Vangheluwe, P.; Freichel, M.; Flockerzi, V.; Voets, T.; Vennekens, $\mathrm{R}$. The $\mathrm{Ca}\left({ }^{2+}\right)$-activated cation channel trpm 4 is a negative regulator of angiotensin ii-induced cardiac hypertrophy. Basic Res. Cardiol. 2015, 110. [CrossRef] [PubMed]

105. Tham, Y.K.; Bernardo, B.C.; Ooi, J.Y.; Weeks, K.L.; McMullen, J.R. Pathophysiology of cardiac hypertrophy and heart failure: Signaling pathways and novel therapeutic targets. Arch. Toxicol. 2015, 89, 1401-1438. [CrossRef] [PubMed]

106. Da Rocha, A.L.; Teixeira, G.R.; Pinto, A.P.; de Morais, G.P.; Oliveira, L.D.C.; de Vicente, L.G.; da Silva, L.; Pauli, J.R.; Cintra, D.E.; Ropelle, E.R.; et al. Excessive training induces molecular signs of pathologic cardiac hypertrophy. J. Cell. Physiol. 2018. [CrossRef] [PubMed]

107. Lopez, J.R.; Linares, N.; Brady, P.A.; Terzic, A. Cardiac hypertrophy determines digitalis action on intracellular $\mathrm{Ca}^{2+}$ in human myocardium. Eur. J. Pharmacol. 1997, 339, 161-164. [CrossRef]

108. Vega, R.B.; Bassel-Duby, R.; Olson, E.N. Control of cardiac growth and function by calcineurin signaling. J. Biol. Chem. 2003, 278, 36981-36984. [CrossRef] [PubMed]

109. Molkentin, J.D.; Lu, J.R.; Antos, C.L.; Markham, B.; Richardson, J.; Robbins, J.; Grant, S.R.; Olson, E.N. a calcineurin-dependent transcriptional pathway for cardiac hypertrophy. Cell 1998, 93, 215-228. [CrossRef]

110. Nishida, M.; Kurose, H. Roles of trp channels in the development of cardiac hypertrophy. Naunyn Schmiedebergs Arch. Pharmacol. 2008, 378, 395-406. [CrossRef] [PubMed]

111. Gao, H.; Wang, F.; Wang, W.; Makarewich, C.A.; Zhang, H.; Kubo, H.; Berretta, R.M.; Barr, L.A.; Molkentin, J.D.; Houser, S.R. Ca $\left({ }^{2+}\right)$ influx through l-type $\mathrm{Ca}\left({ }^{2+}\right)$ channels and transient receptor potential channels activates pathological hypertrophy signaling. J. Mol. Cell. Cardiol. 2012, 53, 657-667. [CrossRef] [PubMed]

112. Ago, T.; Yang, Y.; Zhai, P.; Sadoshima, J. Nifedipine inhibits cardiac hypertrophy and left ventricular dysfunction in response to pressure overload. J. Cardiovasc. Transl. Res. 2010, 3, 304-313. [CrossRef] [PubMed]

113. Horiba, M.; Muto, T.; Ueda, N.; Opthof, T.; Miwa, K.; Hojo, M.; Lee, J.K.; Kamiya, K.; Kodama, I.; Yasui, K. T-type $\mathrm{Ca}^{2+}$ channel blockers prevent cardiac cell hypertrophy through an inhibition of calcineurin-nfat3 activation as well as 1-type $\mathrm{Ca}^{2+}$ channel blockers. Life Sci. 2008, 82, 554-560. [CrossRef] [PubMed]

114. Molkentin, J.D. Calcineurin-nfat signaling regulates the cardiac hypertrophic response in coordination with the mapks. Cardiovasc. Res. 2004, 63, 467-475. [CrossRef] [PubMed]

115. Takahashi, K.; Kakimoto, Y.; Toda, K.; Naruse, K. Mechanobiology in cardiac physiology and diseases. J. Cell. Mol. Med. 2013, 17, 225-232. [CrossRef] [PubMed]

116. Minke, B. Trp channels and $\mathrm{Ca}^{2+}$ signaling. Cell Calcium 2006, 40, 261-275. [CrossRef] [PubMed]

117. Wu, X.; Eder, P.; Chang, B.; Molkentin, J.D. Trpc channels are necessary mediators of pathologic cardiac hypertrophy. Proc. Natl. Acad. Sci. USA 2010, 107, 7000-7005. [CrossRef] [PubMed] 
118. Gueffier, M.; Zintz, J.; Lambert, K.; Finan, A.; Aimond, F.; Chakouri, N.; Hedon, C.; Granier, M.; Launay, P.; Thireau, J.; et al. The trpm 4 channel is functionally important for the beneficial cardiac remodeling induced by endurance training. J. Muscle Res. Cell Motil. 2017, 38, 3-16. [CrossRef] [PubMed]

119. Demion, M.; Thireau, J.; Gueffier, M.; Finan, A.; Khoueiry, Z.; Cassan, C.; Serafini, N.; Aimond, F.; Granier, M.; Pasquie, J.L.; et al. Trpm4 gene invalidation leads to cardiac hypertrophy and electrophysiological alterations. PLoS ONE 2014, 9. [CrossRef] [PubMed]

120. Guinamard, R.; Demion, M.; Magaud, C.; Potreau, D.; Bois, P. Functional expression of the trpm 4 cationic current in ventricular cardiomyocytes from spontaneously hypertensive rats. Hypertension 2006, 48, 587-594. [CrossRef] [PubMed]

121. Collins, H.E.; Zhu-Mauldin, X.; Marchase, R.B.; Chatham, J.C. Stim1/orai1-mediated soce: Current perspectives and potential roles in cardiac function and pathology. Am. J. Physiol. Heart Circ. Physiol. 2013, 305, H446-H458. [CrossRef] [PubMed]

122. Abriel, H.; Syam, N.; Sottas, V.; Amarouch, M.Y.; Rougier, J.S. Trpm 4 channels in the cardiovascular system: Physiology, pathophysiology, and pharmacology. Biochem. Pharmacol. 2012, 84, 873-881. [CrossRef] [PubMed]

123. Mathar, I.; Vennekens, R.; Meissner, M.; Kees, F.; Van der Mieren, G.; Camacho Londono, J.E.; Uhl, S.; Voets, T.; Hummel, B.; van den Bergh, A.; et al. Increased catecholamine secretion contributes to hypertension in trpm4-deficient mice. J. Clin. Investig. 2010, 120, 3267-3279. [CrossRef] [PubMed]

124. Mathar, I.; Kecskes, M.; Van der Mieren, G.; Jacobs, G.; Camacho Londono, J.E.; Uhl, S.; Flockerzi, V.; Voets, T.; Freichel, M.; Nilius, B.; et al. Increased beta-adrenergic inotropy in ventricular myocardium from trpm4-/mice. Circ. Res. 2014, 114, 283-294. [CrossRef] [PubMed]

125. Bhatnagar, P.; Wickramasinghe, K.; Wilkins, E.; Townsend, N. Trends in the epidemiology of cardiovascular disease in the uk. Heart 2016, 102, 1945-1952. [CrossRef] [PubMed]

126. Finegold, J.A.; Asaria, P.; Francis, D.P. Mortality from ischaemic heart disease by country, region, and age: Statistics from world health organisation and united nations. Int. J. Cardiol. 2013, 168, 934-945. [CrossRef] [PubMed]

127. Khera, A.V.; Kathiresan, S. Genetics of coronary artery disease: Discovery, biology and clinical translation. Nat. Rev. Genet. 2017, 18, 331-344. [CrossRef] [PubMed]

128. Ford, T.J.; Corcoran, D.; Berry, C. Coronary artery disease: Physiology and prognosis. Eur. Heart J. 2017, 38, 1990-1992. [CrossRef] [PubMed]

129. Cassar, A.; Holmes, D.R., Jr.; Rihal, C.S.; Gersh, B.J. Chronic coronary artery disease: Diagnosis and management. Mayo Clin. Proc. 2009, 84, 1130-1146. [CrossRef] [PubMed]

130. Carden, D.L.; Granger, D.N. Pathophysiology of ischaemia-reperfusion injury. J. Pathol. 2000, 190, $255-266$. [CrossRef]

131. Cadenas, S. Ros and redox signaling in myocardial ischemia-reperfusion injury and cardioprotection. Free Radic. Biol. Med. 2018, 117, 76-89. [CrossRef] [PubMed]

132. Frank, A.; Bonney, M.; Bonney, S.; Weitzel, L.; Koeppen, M.; Eckle, T. Myocardial ischemia reperfusion injury: From basic science to clinical bedside. Semin. Cardiothorac. Vasc. Anesth. 2012, 16, 123-132. [CrossRef] [PubMed]

133. Kalogeris, T.; Baines, C.P.; Krenz, M.; Korthuis, R.J. Cell biology of ischemia/reperfusion injury. Int. Rev. Cell Mol. Biol. 2012, 298, 229-317. [PubMed]

134. Consolini, A.E.; Ragone, M.I.; Bonazzola, P.; Colareda, G.A. Mitochondrial bioenergetics during ischemia and reperfusion. Adv. Exp. Med. Biol. 2017, 982, 141-167. [PubMed]

135. Launay, P.; Cheng, H.; Srivatsan, S.; Penner, R.; Fleig, A.; Kinet, J.P. Trpm4 regulates calcium oscillations after $\mathrm{t}$ cell activation. Science 2004, 306, 1374-1377. [CrossRef] [PubMed]

136. Hadi, H.A.; Carr, C.S.; Al Suwaidi, J. Endothelial dysfunction: Cardiovascular risk factors, therapy, and outcome. Vasc. Health Risk Manag. 2005, 1, 183-198. [PubMed]

137. Widmer, R.J.; Lerman, A. Endothelial dysfunction and cardiovascular disease. Glob. Cardiol. Sci. Pract. 2014, 2014, 291-308. [CrossRef] [PubMed]

138. Ding, X.Q.; Ban, T.; Liu, Z.Y.; Lou, J.; Tang, L.L.; Wang, J.X.; Chu, W.F.; Zhao, D.; Song, B.L.; Zhang, Z.R. Transient receptor potential melastatin 4 (trpm4) contributes to high salt diet-mediated early-stage endothelial injury. Cell. Physiol. Biochem. 2017, 41, 835-848. [CrossRef] [PubMed] 
139. Becerra, A.; Echeverria, C.; Varela, D.; Sarmiento, D.; Armisen, R.; Nunez-Villena, F.; Montecinos, M.; Simon, F. Transient receptor potential melastatin 4 inhibition prevents lipopolysaccharide-induced endothelial cell death. Cardiovasc. Res. 2011, 91, 677-684. [CrossRef] [PubMed]

140. Simard, J.M.; Woo, S.K.; Gerzanich, V. Transient receptor potential melastatin 4 and cell death. Pflugers Arch. 2012, 464, 573-582. [CrossRef] [PubMed]

141. Gerzanich, V.; Woo, S.K.; Vennekens, R.; Tsymbalyuk, O.; Ivanova, S.; Ivanov, A.; Geng, Z.; Chen, Z.; Nilius, B.; Flockerzi, V.; et al. De novo expression of trpm4 initiates secondary hemorrhage in spinal cord injury. Nat. Med. 2009, 15, 185-191. [CrossRef] [PubMed]

142. Earley, S.; Brayden, J.E. Transient receptor potential channels and vascular function. Clin. Sci. 2010, 119, 19-36. [CrossRef] [PubMed]

143. Simon, F.; Fernandez, R. Early lipopolysaccharide-induced reactive oxygen species production evokes necrotic cell death in human umbilical vein endothelial cells. J. Hypertens. 2009, 27, 1202-1216. [CrossRef] [PubMed]

144. Simon, F.; Leiva-Salcedo, E.; Armisen, R.; Riveros, A.; Cerda, O.; Varela, D.; Eguiguren, A.L.; Olivero, P.; Stutzin, A. Hydrogen peroxide removes trpm 4 current desensitization conferring increased vulnerability to necrotic cell death. J. Biol. Chem. 2010, 285, 37150-37158. [CrossRef] [PubMed]

(C) 2018 by the authors. Licensee MDPI, Basel, Switzerland. This article is an open access article distributed under the terms and conditions of the Creative Commons Attribution (CC BY) license (http:/ / creativecommons.org/licenses/by/4.0/). 